\title{
Journal of Addictions and Therapies
}

Research Article

Anari AMZ, et al. J Addict Ther 2016: G109.

DOI: 10.29011/JATP-109/100009

\section{Complicated Grief in Iranian Methadone Maintenance Clients}

\author{
Ali Kheradmand1, Alireza Ghaffarinejad2, Ali Mehdizadeh Zare Anari3*, Fatemeh Noroozi4 \\ ${ }^{1}$ Taleghani Hospital Research Development Committee , Behavioral Sciences Research Center, Shahid Beheshti University of Medical \\ Sciences, Tehran, Iran \\ ${ }^{2}$ Neuroscience Research Center, Kerman University of Medical Sciences, Kerman, Iran \\ ${ }^{3 *}$ Scholar of Neuroscience Research Center and psychiatrist of Afzali pour Hospital. Kerman, Iran \\ ${ }^{4}$ Kerman University of Medical Sciences, Kerman, Iran
}

"Corresponding author: Ali Mehdizadeh Zare Anari, Neuroscience Research Center and psychiatrist of Afzalipour Hospital. Kerman, Iran, Tel: +40 744757 211; Tel: +98-2122171075; E-mail: mehdizadeh93@gmail.com

Citation: Kheradmand A, Ghaffarinejad A, Anari AMZ, Noroozi F (2016) Complicated Grief in Iranian Methadone Maintenance Clients. Gavin J Addict Ther 2016: G109. DOI: 10.29011/JATP-109/100009

Received Date: 1 November, 2016; Accepted Date: 17 November, 2016; Published Date: 29 December, 2016

\begin{abstract}
Complicated grief causes clearly functional disorders, and grief signs lasts at least a month after six months going through unfortunate incident. Researches about grief and complicated grief, Requires a deeper understanding in etiology of creation and several therapeutic procedures. In this study we want to evaluate the relationship between the use of methadone and complicated grief. Among methadone consumers in cessation drug centers in Mashhad in 2015 a sample of 285 people's chose randomly to answer Inventory of Complicated Grief (ICG test (and demographic questionnaire. Complicated grief is more frequent in men than women and more in middle-aged people than the other ages. The most frequent complicated grief among those with post graduate diploma and the lowest rate is among Postgraduate. People who have lost their first-grade relatives have more complicated grief than those who lost the other ones. The individuals who have lost some one due to disease are more frequent than those who have lost some one suddenly. Finding of this research showed that Men, people with post graduate diploma and people who have lost their first-grade relatives have experienced more complicated grief. Gender of deceased and marital status do not effect on the frequency of complicated grief.
\end{abstract}

Keywords: Complicated grief; Methadone; Iran

\section{Introduction}

Grief is a subjective feeling that one of the reasons is the loved ones death. Grief naturally would be resolved within a few months $[1,2]$, and the person will return to his normal function. During this time some symptoms occurs in person such as feelings of aggression, anger and crying [3]. Complicated grief is a condition that the grief deviates from the expected path so that it associates with extensive or prolonged mental or physical morbidity and is related to increased depression, substance abuse, suicide, insomnia and mortality. Patient has disturbing mental images, denying death of the deceased, neglect of daily activities, avoidance of thinking about death and the places remember death and apathy toward others.
In previous studies, the prevalence of complicated grief in the general population has been reported from $2 / 4$ to $6 / 4 \%$ [2], in another study this rate reported $10 \%$ and in other study the rates were reported until 20\% [4]. The most common complicated grief is chronic and lasted one [1], that it characterized by idealizing deceased and is more common when the relationship between the bereaved and the deceased has been super closed and with more dependency [3]. Extreme grief caused over the sudden and unexpected death, and the reactions to grief is ultra-serious and intemperate. Extreme grief has often long journey, however decreases over the time [3]. Controlled grief is when the signs and symptoms of acute grief are expected, but the grief has been postponed; which is characterized by long denial, then anger and guilt may complicate the course of this disorder [3]. Grief may cause changes in method of dealing with problems and stresses. Those who have problems naturally in passing the stages of grief, their physical 
Citation: Kheradmand A, Ghaffarinejad A, Anari AMZ, Noroozi F (2016) Complicated Grief in Iranian Methadone Maintenance Clients. Gavin J Addict Ther 2016: G109.

and mental health are at risk [5]. Stress and anxiety, as well as nonadaptive approaches to problems, can complicate the grief [6].

A way for non-adaptive dealing with problems is turning to drugs. Drug abuse has always been an issue and concern of different societies. Several factors, such as social factors involve in creation of addiction [7]. Substance abuse is a tragedy for the consumer, his family and the society; therefore, it is known as a crime and main cause of social, economic and health problems [8]. The process of drug dependency is on the rise in countries such as China, India, Indonesia, Russia and Iran [9].

Methadone is a synthetic opioid with a pure agonist nature with long half-life and with a very strong analgesic effect. Half-life of this substance has mentioned from 25 to more than 52 hours [10]. It's Consumption, as drink and pills, has been common in Iran in recent years to relieve severe pain and addictions [11]. Methadone is an only allowed opiate substance which is used for long-term treatment of opioid dependents, and it is an opioid analgesic, including the most important effects on the central nervous system such as: analgesia, euphoria and sedation [12]. Methadone maintenance treatment (MMT) has been identified as an effective, safe, cost effective international intervention for drug-dependent individuals $[13,14]$.

In a study conducted previously showed that women more than men have experienced complicated grief; and complicated grief occurs in deceased partners more than their parents, brothers and sisters. If cancer and heart disease be the leading cause of death, more pathological grief occurs in his relatives [2]. In a study that was done on survivors of the Bam earthquake, it was found that $76 \%$ of them had complicated grief and at least one first-grade relative of people who died during the earthquake, had more complicated grief and this rate was higher in those with lower level of education [15]. In a study on American soldiers who participated in the war between Afghanistan and America, it was found that over $20 \%$ of them are having difficulty resolving and dealing with grief and people who are caught in this category, are at risk of physical and mental health [5].

Therapeutic interventions, both pharmacological and nonpharmacological took on complicated grief, has been shown to have beneficial effects in reducing symptoms of pathological grief $[3,4,19]$.Loss of a loved one's is considered as a great stress in the life of a person, people for reducing its suffering may use then on-adaptive mechanisms, such as drugs, alcohol or tobacco that it could threaten their physical and mental health in future. Research on complicated grief and grief requires a deeper understanding of its etiology and different ways of treatment, in this study we want to evaluate the relationship between the methadone consumption and complicated grief.

\section{Materials and Methods}

This research is causal-comparative and cross-sectional study. The study population included all 2,000 methadone consumers in cessation drug centers in Mashhad city in 2015. About these 2000 persons by coordination with all the cessation drug centers in Mashhad, Iran. By study of their files, we knew that 700 of them have lost a person in their past year and finally according to Morgan 285peoplewererandomly selected. The method was simple random sampling. At first the questionnaires that included demographic characteristics of individuals were completed, and the aim of the study was explained, and informed consent was obtained from participants. People who care only for methadone maintenance treatment participated in this study. It also asked people about the death of someone close. People with a history of death of a family member, completed the grief questionnaire.

The materials used was Grief Questionnaire (19 questions with five degrees for the grief), and Demographic Questionnaire. Inventory of Complicated Grief or ICG test is as elf-report test to measure the severity of grief. Scores range is from zero to 78. This test consists of19sections and each section, based on the severity of the grief score, is between zeros to four. People whose score is more than 25 are known as complicated grief. The validity and reliability of the questionnaire study measured by Pygirson [30] and Cranach's alpha for this questionnaire measured0/94, this test used for complicated grief in Bam by the author [31,15]. Finally 285 questionnaires analyzed. For data analyzing first we used Kolmogorov - Smirnov exam to measure normal distribution in all features. And we used descriptive statistics for average, standard deviation, maximum and minimum score, frequency and percent of frequency. And Chi-square, T-test and ANOVA used for statistics analysis.

\section{Results}

Results of descriptive statistics showed that, People with an average age of $42 / 67 \pm 13 / 18$, and among subjects responsive: 25 $(8 / 77 \%)$ had normal grief, $260(91 / 22 \%)$ had complicated grief, in terms ofeducation75 (26/6\%) illiterate, 81 (30/9\%) cycle, 89 $(34 / 0 \%)$ diplomaand17 (6/50\%) license and higher degrees. Chisquare analysis, comparing the relationship between complicated grief and gender (Table1).

\begin{tabular}{|c|c|c|c|c|c|c|c|c|c|}
\hline Chi & df & $\mathbf{P}$ & & Total & Cor & licated grief & & mal grief & Grief \\
\hline \multirow{4}{*}{$01 / 0$} & \multirow{4}{*}{1} & \multirow{4}{*}{$6 / 01$} & Frequency & Frequency percent & Frequency & Frequency percent & Frequency & Frequency percent & Gender \\
\hline & & & 199 & $56 / 70$ & 176 & $41 / 62$ & 23 & $15 / 8$ & man \\
\hline & & & 83 & $43 / 29$ & 81 & $72 / 28$ & 2 & $07 / 0$ & woman \\
\hline & & & 282 & 100 & 81 & $13 / 91$ & 25 & $85 / 8$ & total \\
\hline
\end{tabular}

Table 1: Chi-square analysis to compare between complicated and normal grief by gender 
Citation: Kheradmand A, Ghaffarinejad A, Anari AMZ, Noroozi F (2016) Complicated Grief in Iranian Methadone Maintenance Clients. Gavin J Addict Ther 2016: G109.

Determine that there is significant difference between the prevalence of complicated grief and gender, so that complicated grief is more common among men than women $(\mathrm{p}=0.01)$. Chi-square analysis, comparing the relationship between complicated grief and marital statue showed that there is not a significant difference between complicated grief and marital statue $(\mathrm{p}=0 / 3)$.

Chi-square results, the relationship between complicated grief and educational statue (Table 2).

\begin{tabular}{|c|c|c|c|c|c|c|c|c|c|}
\hline $\mathbf{P}$ & df & Chi & \multicolumn{2}{|c|}{ Total } & \multicolumn{2}{|c|}{ Complicated grief } & \multicolumn{2}{|c|}{ Normal grief } & \multirow{2}{*}{$\begin{array}{c}\text { Grief } \\
\text { Educational } \\
\text { statue }\end{array}$} \\
\hline \multirow{6}{*}{$0 / 03$} & & \multirow{6}{*}{$104 / 24$} & $\begin{array}{c}\text { Frequency } \\
\text { percent }\end{array}$ & frequency & Frequency percent & frequency & Frequency percent & frequency & \\
\hline & & & 28.62 & 75 & 27.86 & 73 & 0.76 & 2 & illiterate \\
\hline & & & 30.91 & 81 & 27.86 & 73 & 3.05 & 8 & cycle \\
\hline & & & 33.96 & 89 & 29.77 & 78 & 4.19 & 11 & diploma \\
\hline & & & 5.75 & 15 & 4.19 & 11 & 1.52 & 4 & bachelor \\
\hline & & & 0.76 & 2 & 0.76 & 2 & 0 & 0 & Postgraduate \\
\hline & & & 100 & 262 & 90.45 & 237 & 9.54 & 25 & total \\
\hline
\end{tabular}

Table 2: Results of the chi-square test for comparing normal and complicated grief in different educational statue.

Showed that there is a significant difference between the prevalence of complicated grief and level of education, so that The highest prevalence of complicated grief is among people with diploma and a master's degree is the lowest rate among them $(p=0.03)$. Chisquare results, the relationship between complicated grief and gender showed that there is not any correlation between the prevalence of complicated grief and deceased gender $(\mathrm{p}=0.08)$.

Chi-square test results to compare between pathological grief and relationship with the deceased (table 3).

\begin{tabular}{|c|c|c|c|c|c|c|c|c|c|}
\hline $\mathbf{P}$ & df & Chi & \multicolumn{2}{|c|}{ Total } & \multicolumn{2}{|c|}{ complicated grief } & \multicolumn{2}{|c|}{ Normal grief } & \multirow{2}{*}{$\begin{array}{c}\text { grief } \\
\begin{array}{c}\text { Relationship with the } \\
\text { deceased }\end{array}\end{array}$} \\
\hline & \multirow{7}{*}{\multicolumn{2}{|c|}{$8 \quad 0 / 4001$}} & $\begin{array}{c}\text { Frequency per- } \\
\text { cent }\end{array}$ & frequency & $\begin{array}{c}\text { Frequency per- } \\
\text { cent }\end{array}$ & $\begin{array}{c}\text { frequen- } \\
\text { cy }\end{array}$ & $\begin{array}{c}\text { Frequency per- } \\
\text { cent }\end{array}$ & $\begin{array}{l}\text { frequen- } \\
\text { cy }\end{array}$ & \\
\hline & & & $48 / 77$ & 139 & $47 / 36$ & 135 & $1 / 40$ & 4 & First-Grade relatives \\
\hline & & & $13 / 68$ & 39 & $11 / 57$ & 33 & $2 / 10$ & 6 & second-Grade relatives \\
\hline & & & $10 / 87$ & 31 & $10 / 17$ & 29 & $0 / 70$ & 2 & partner \\
\hline & & & $16 / 49$ & 47 & $15 / 74$ & 45 & $0 / 70$ & 2 & friend \\
\hline & & & $10 / 17$ & 29 & $6 / 31$ & 18 & $3 / 85$ & 11 & others \\
\hline & & & 100 & 285 & $91 / 22$ & 260 & $6 / 25$ & 25 & total \\
\hline
\end{tabular}

Table 3: Chi-square test results to compare between complicated and normal grief in terms of relationship with the deceased.

Showed that there is significant difference between pathological grief and relationship with the deceased, so that the highest prevalence of pathological grief is among those who have lost their first-Grade relatives and least common is in people who have lost others $(\mathrm{p}=0.001)$.

Chi-square test results to compare between complicated grief and cause of death (table 4).

\begin{tabular}{|c|c|c|c|c|c|c|c|c|c|}
\hline $\mathbf{P}$ & df & Chi & \multicolumn{2}{|l|}{ Total } & \multicolumn{2}{|c|}{ complicated grief } & \multicolumn{2}{|c|}{ Normal grief } & grief \\
\hline \multirow{4}{*}{$0 / 01$} & \multirow{4}{*}{1} & \multirow{4}{*}{$5 / 4$} & Frequency percent & frequency & Frequency percent & frequency & Frequency percent & frequency & cause of deat \\
\hline & & & $53 / 69$ & 152 & $46 / 99$ & 133 & $6 / 7$ & 19 & disease \\
\hline & & & $46 / 28$ & 131 & $44 / 169$ & 125 & $2 / 12$ & 6 & Sudden or incident \\
\hline & & & 100 & 283 & $91 / 16$ & 258 & $8 / 83$ & 25 & total \\
\hline
\end{tabular}

Table 4: Chi-square test results to compare between complicated and normal grief in terms of cause of death.

Showed that there is a significant difference between complicated grief and cause of death, so that complicated grief among those who have lost someone due to disease is more common than people who suddenly have lost someone $(\mathrm{p}=0.01)$.

Chi-square analysis in relationship between complicated grief and type of substance abuse showed that there is not any association between the prevalence of complicated grief and type of substance abuse $(\mathrm{p}=0.18)$. 
Citation: Kheradmand A, Ghaffarinejad A, Anari AMZ, Noroozi F (2016) Complicated Grief in Iranian Methadone Maintenance Clients. Gavin J Addict Ther 2016: G109.

The results of the comparison tendency to method one before and after the unfortunate event by T test (Table 5).

\begin{tabular}{|c|c|c|c|c|c|c|c|}
\hline \multirow{2}{*}{$\mathbf{t}$} & Degree of freedom & \multirow{2}{*}{$\mathbf{p}$} & $\begin{array}{c}\text { Standard devia- } \\
\text { tion }\end{array}$ & average & number & $\begin{array}{c}\text { Tendency to } \\
\text { methadone }\end{array}$ \\
\cline { 4 - 7 } & & & $17 / 76$ & $2 / 99$ & 267 & Before the unfortunate event & After the unfortunate even \\
\hline 509 & $-304 / 9 * *$ & $001 / 0$ & $2 / 17$ & $4 / 61$ & 244 & . \\
\hline
\end{tabular}

Table 5: result of t-test to compare tendency to methadone.

Showed that there is a significant difference between tendency to method one before and after the unfortunate event $(\mathrm{P}<0 / 05)$, this means that the tendency to method one after the unfortunate event $(T=4 / 61)$ is more than before unfortunate event $(T=2 / 99)$.

Comparing the grief and complicated grief at different ages by ANOVA test (Table 6).

\begin{tabular}{|c|c|c|c|c|c|c|c|}
\hline & & $\mathbf{6 0}>$ & $\mathbf{5 1 - 6 0}$ & $\mathbf{4 1 - 5 0}$ & $\mathbf{3 1 - 4 0}$ & $\mathbf{2 1 - 3 0}$ & age \\
\hline $\mathbf{P}$ & $\mathbf{F}$ & $\mathbf{M} \pm$ SD & $\mathbf{M} \pm$ SD & $\mathbf{M} \pm$ SD & M \pm SD & M \pm SD & \\
\hline $0 / 008$ & $3 / 51$ & $43 / 86 \pm 15 / 19$ & $36 / 35 \pm 14 / 53$ & $39 / 87 \pm 15 / 06$ & $48 / 64 \pm 15 / 6$ & $37 / 34 \pm 13 / 7$ & grief \\
\hline $0 / 002$ & $4 / 31$ & $47 / 97 \pm 13 / 87$ & $41 / 23 \pm 12 / 91$ & $42 / 41 \pm 13 / 87$ & $49 / 74 \pm 11 / 82$ & $44 / 9 \pm 9 / 4$ & complicated grief \\
\hline
\end{tabular}

Table 6: ANOVA test results to compare the grief and pathological grief in terms of age.

Showed significant differences between grief and different ages $(\mathrm{P}=0.008)$. It can be concluded that grief in people over50 years $(\mathrm{T}=$ $36 / 35$ ) is lowest and in 31-40years is highest among all different age groups. Compare of complicated grief at different ages by ANOVA test showed significant difference in complicated grief at different ages $(\mathrm{p}=0.002)$. It can be concluded that complicated grief in people 51-60 years $(\mathrm{T}=36 / 35)$ is lowest and in 31-40years is highest among all different age groups. According to (Table 7).

\begin{tabular}{|c|c|c|c|c|c|c|c|}
\hline Total & always & often & $\begin{array}{l}\text { some- } \\
\text { times }\end{array}$ & rarely & never & $\begin{array}{c}\text { Frequency and } \\
\text { Frequency } \\
\text { percent }\end{array}$ & Number of question \\
\hline 285 & 47 & 73 & 92 & 53 & 20 & number & \multirow{2}{*}{$\begin{array}{l}\text { I think about this person so much that it's hard for me to } \\
\text { do things I normally do }\end{array}$} \\
\hline 100 & $16 / 5$ & $25 / 7$ & $32 / 3$ & $18 / 6$ & 7 & percent & \\
\hline 285 & 105 & 97 & 70 & 8 & 5 & number & \multirow{2}{*}{ Memory of the person who died upsets me } \\
\hline 100 & $36 / 8$ & 34 & $24 / 6$ & $2 / 8$ & $1 / 8$ & percent & \\
\hline 285 & 74 & 75 & 92 & 34 & 10 & number & \multirow{2}{*}{ I feel I cannot accept the death of the person who died } \\
\hline 100 & 26 & $26 / 3$ & $23 / 3$ & $11 / 9$ & $3 / 5$ & percent & \\
\hline 285 & 192 & 61 & 30 & 0 & 2 & number & \multirow{2}{*}{$\begin{array}{l}\text { I feel drawn to places and things associated with the } \\
\text { person who died }\end{array}$} \\
\hline 100 & $67 / 4$ & $21 / 4$ & $10 / 5$ & 0 & 7 & percent & \\
\hline 285 & 44 & 76 & 83 & 39 & 43 & number & \multirow{2}{*}{ I feel disable over what happened } \\
\hline 100 & $15 / 4$ & $26 / 7$ & $29 / 2$ & $13 / 7$ & $15 / 1$ & percent & \\
\hline 285 & 45 & 98 & 86 & 39 & 17 & number & \multirow{2}{*}{$\begin{array}{l}\text { I go out of my way to avoid reminders of the person who } \\
\text { died }\end{array}$} \\
\hline 100 & $15 / 8$ & $34 / 4$ & $30 / 2$ & $13 / 7$ & 6 & percent & \\
\hline 285 & 33 & 63 & 61 & 63 & 65 & number & \multirow{2}{*}{ I feel that life is empty without the person who died } \\
\hline 100 & $11 / 6$ & $22 / 1$ & $21 / 4$ & $22 / 1$ & $22 / 8$ & percent & \\
\hline 285 & 39 & 66 & 84 & 54 & 42 & number & \multirow{2}{*}{$\begin{array}{l}\text { I feel that it is unfair that I should live when this person } \\
\text { died }\end{array}$} \\
\hline 100 & $13 / 7$ & $23 / 2$ & $29 / 5$ & $18 / 9$ & $14 / 7$ & percent & \\
\hline 285 & 44 & 91 & 51 & 65 & 34 & number & \multirow{2}{*}{ I feel disabled over what happened } \\
\hline 100 & $15 / 4$ & $31 / 9$ & $17 / 9$ & $8 / 22$ & 9/11 & percent & \\
\hline 285 & 68 & 92 & 61 & 47 & 17 & number & \multirow{2}{*}{ I hear the voice of the person who died speaks to me } \\
\hline 100 & $23 / 9$ & $23 / 23$ & $21 / 4$ & $16 / 5$ & 6 & percent & \\
\hline
\end{tabular}


Citation: Kheradmand A, Ghaffarinejad A, Anari AMZ, Noroozi F (2016) Complicated Grief in Iranian Methadone Maintenance Clients. Gavin J Addict Ther 2016: G109.

\begin{tabular}{|c|c|c|c|c|c|c|c|}
\hline 285 & 45 & 66 & 50 & 58 & 66 & number & I feel lonely a great deal of the time ever since she/he \\
\hline 100 & $15 / 8$ & $23 / 2$ & $17 / 5$ & $20 / 4$ & $23 / 2$ & percent & died \\
\hline 285 & 59 & 79 & 82 & 35 & 30 & number & \multirow{2}{*}{ I can't help feeling angry about his/her death } \\
\hline 100 & $20 / 7$ & $27 / 7$ & $28 / 8$ & $12 / 3$ & $10 / 5$ & percent & \\
\hline 285 & 45 & 57 & 79 & 50 & 54 & number & \multirow{2}{*}{ I feel- myself longing for the person who died } \\
\hline 100 & $15 / 8$ & 20 & $27 / 7$ & $17 / 5$ & $18 / 9$ & percent & \\
\hline 285 & 77 & 89 & 63 & 39 & 17 & number & \multirow{2}{*}{ I feel stunned or dazed over what happened } \\
\hline 100 & 27 & $31 / 2$ & $22 / 1$ & $13 / 7$ & 6 & percent & \\
\hline 285 & 186 & 55 & 36 & 6 & 2 & number & \multirow{2}{*}{ Ever since she/he died it is hard for me to trust people } \\
\hline 100 & $65 / 3$ & $19 / 3$ & $12 / 6$ & $2 / 1$ & 7 & percent & \\
\hline 285 & 47 & 87 & 91 & 35 & 25 & number & \multirow{2}{*}{$\begin{array}{l}\text { Ever since she/he died I feel like I have lost the ability } \\
\text { to care about other people or I feel distant from people I } \\
\text { care about }\end{array}$} \\
\hline 100 & $16 / 5$ & $30 / 5$ & $31 / 9$ & $12 / 3$ & $8 / 8$ & percent & \\
\hline 285 & 26 & 64 & 36 & 75 & 84 & number & \multirow{2}{*}{$\begin{array}{l}\text { I have pain in the same area of my body or have some of } \\
\text { the same syndromes as the person who died }\end{array}$} \\
\hline 100 & $9 / 1$ & $22 / 5$ & $12 / 6$ & $26 / 3$ & $29 / 5$ & percent & \\
\hline 285 & 9 & 69 & 82 & 44 & 81 & number & \multirow{2}{*}{ I see the person who died stand before me } \\
\hline 100 & $3 / 2$ & $24 / 2$ & $28 / 8$ & $15 / 4$ & $28 / 4$ & percent & \\
\hline 285 & 30 & 64 & 78 & 55 & 58 & number & \multirow{2}{*}{$\begin{array}{l}\text { I feel envious of other people who have not lost someone } \\
\text { close }\end{array}$} \\
\hline 100 & $10 / 5$ & $22 / 5$ & $27 / 4$ & $19 / 3$ & $20 / 4$ & percent & \\
\hline
\end{tabular}

Table 7: frequency and percentage distribution of those who have complicated grief according to ICG test.

Question18 (I see the person who died stand before me) has least association with complicated grief and Question 4 (I feel drawn to places and things associated with the person who died) has most association with complicated grief.

\section{Discussion}

Grief or sadness and sorrow, is a normal physiological response to an unfortunate incident such as missing a person, that sometimes causing debilitating syndrome that consists of persistent and severe symptoms that interfere with daily life [15]. Studies have shown that in people who have a drug addiction, grief lasted more than the general population. And long-term effects of grief show itself on individuals by psychiatric symptoms, especially depression and anxiety disorder [20-22]. Among these some issues increases the risk of grief, that some of the mare mentioned in the study. In the present study found that the scores by ICG test are more in men than women. Christen study which was done on people with grief showed that the grief happens in women slightly more than men, but this difference was not statistically significant [1]. In another study by Justin, on the elderly persons50to 93years old, who had lost their partner, there was no difference in none of genders (male or female)in event and the severity of grief [2], which is not in line with findings of this study. In our study there was no significant difference in complicated grief among the single, married and divorced individuals. Schulz study showed that there is no significant difference in complicated grief between married and singles, which is in line with our study [3,4]. In the present study it was shown that complicated grief occurs more in tensely in the middle aged groups than any other age. In the Moss study, as our study, has shown that complicated grief occurs more in the middle aged and is more severe in them [5]. In case study on parents who lost their child, showed that middle aged parents had higher scores in complicated grief than the younger parents [6]. Also the results of this study showed that the complicated grief in participants of this study has a significant difference with the level of education, and in postgraduate diploma is the most. KhalilZade study showed that there is not a significant difference between grief and level of education, in this study, against our study, the number of people with a university degree was more, and showed that by increasing the level of education the grief decrease or not increase, and the grief score in different education levels did not differ [7]. In case study these verity and intensity of grief is not different for people with different level of education [6], which is not in line with the findings of our study. The results of our study showed that after the creation of unfortunate incident and grief, Tendency to drug abuse, will significantly increase. Several studies have shown that in addicts there is an important psychiatric field, such as depression, personality disorder, grief reactions and so on [8]. Fur study, which was conducted on addicts, showed that drug addiction treatment, had more failure in those who had grief than people who did not have grief reactions [9]. Zuck off study that was conducted on addicts showed that individuals, who were treated in grief, had 
Citation: Kheradmand A, Ghaffarinejad A, Anari AMZ, Noroozi F (2016) Complicated Grief in Iranian Methadone Maintenance Clients. Gavin J Addict Ther 2016: G109.

greater success in drug addiction treat men than those who had not received any treatment [10]. In Laurson study showed that parents who were lost their children have higher number of hospital admissions due to drug abuse than those who did not [11], which is in line with the findings of our study.

\section{Conclusion}

The findings of our study, on the whole, represented significant vulnerability in addicts in face of grief, So that they are not able to spend natural process of grief as ordinary people, so they show more emotional, physical, cognitive and behavioral symptoms. Therefore a big attention for officials about the prevention and treatment of addicts, that by use of these findings, be concerned to find cause of this issues, and have more attention to the prevention of psychiatric symptoms of grief and complicated grief. The person after unfortunate incident for calming, increase the consumption of methadone.

\section{Acknowledgments}

We want to cooperate sincerely thank to Kerman Neuroscience Research Center that under take budget of project and those who agreed to carry out the research project in Mashhad.

\section{References}

1. Wright AA, Zhang B, Ray A, Mack JW, Trice E, et al. (2008) Associations between end-of-life discussions, patient mental health, medical care near death, and caregiver bereavement adjustment. JAMA 300:1665-1673.

2. Reynolds FC, Stack J,Houle J (2016) Diagnosis and treatment of complicated grief. psychiatry for consults and referrals 2016: 1-7.

3. Kowalski SD, Bondmass MD (2008) Physiological and psychological symptoms of grief in widows. Research in nursing \& health 31: 23-30.

4. Deno M, Miyashita M, Fujisawa D, Satomi N, Ito M (2011) The relationships between complicated grief, depression, and alexithymia according to the seriousness of complicated grief in the Japanese general population. Journal of Affective Disorders 135: 122-127.

5. Toblin RL, Riviere LA, Thomas JL, Adler AB, Kok BC (2012) Grief and physical health outcomes in U.S.Soldiers returning from combat, Journal of Affective Disorders 136: 469-475.

6. Bui E, LeBlanc N, Morris Lk, Marques L, Shear Mk, Simon NM (2013) Panic-agoraphobic spectrum symptoms in complicated grief. J psychres 209: 118-120.

7. Martinotta G, Carlib V, Tedeschia D, Digiannantonioc M, Royd A, et al (2009) Addictive Behaviors 34: 790-793.

8. Xiao L, Wu Z, Luo W, Wei X (2010) Quality of Life of Outpatients in Methadone Maintenance Treatment Clinics. J Acquir Immune Defi Syndr 53: 116-120.

9. Degenhardt L, Hall WD, Warner-Smith M, Lynskey MT (2004) Illicit drug use: In: Comparative quantification of health risks: global and regional burden of disease attributable to selected major risk factor)
Ezzati M, Lopez A, Rodgers A, Murray C, ed.). Geneva: World Health Organization: 1109-1176.

10. Alterman Al, McDermott PA, Cacciola JS, Rutherford MJ (2003) Latent structure of the Davis Interpersonal Reactivity Index in methadone maintenance patients. Journal of Psychopathology and Behavioral Assessment 25: 257-265.

11. Connock M, Juarez-Garcia A, Jowett S, Frew E, Liu Z, et al (2007) Methadone and buprenorphine for the management of opioid dependence: a systematic review and economic evaluation. Health Technol Assess 11:1-171.

12. Langleben DD, Ruparel K, Elman I, Busch-Winokur S, Pratiwadi R, et al (2008) Acute effect of methadone maintenance dose on brain FMRI response to heroin-related cues. American Journal of Psychiatry 165: 390-394.

13. Erdelyan M, Young C (2009) Methadone maintenance treatment: A community planning guide. Toronto: Centre for Addiction and Mental Health.

14. World Health Organization: Office on Drugsand Crime. (2004). WHO/ UNODC/UNAIDS Position Paper: Substitution MaintenanceTherapy in the Management of Opioid methadone maintenance treatment program, Quality of life and health of opioid dependent persons in Lithuania. Medicina Kaunas 43: 235-241.

15. Ghaffari-nejad A, Ahmadi-mousavi M, Gandomkar M, Reihani-kermani $H$ (2007) The prevalence of complicated grief among bam earthquake survivors in Iran. Arch Iranian med 10: 525-528.

16. Wittouck C, Van Autreve S, De Jaegere E, Portzky G, Van Heeringen $\mathrm{K}$ (2011) The prevention and treatment of complicated grief: A metaanalysis. Clinical Psychology Review 31: 69-78.

17. Hayes SC, Wilson KG, Gifford EV, Bissett R, Piasecki M, et al (2004) A preliminary trial of twelve-step facilitation and acceptance and commitment therapy with polysubstance-abusing methadone-maintained opiate addicts. Behavior Therapy 35: 667-688.

18. Callaly T, Trauer T, Munro L, Whelan G (2001) Prevalence of psychiatric Disorder in a methadone18-Maintenance population. Aust NZ J psychiatry 35: 601-605.

19. O'Connor M, Shear K, Fox R, Skritskaya N, Campbell B, et al (2013) Catecholamine predictors of complicated greif treatment outcomes, International Journal of Psychophysiology, Volume 88, Issue 3, June 2013, Pages 349-352.

20. Saduk B, Sadock V (2016) Synopsis of Psychiatry: Behavioral Sciences and Clinical Psychiatry. The Journal of Urmia University of Medical Sciences, Arjmand 1388: 240-263.

21. Furr SR, Johnson WD, Goodall CS (2005) Grief and Recovery: The Prevalence of Grief and Loss in Substance Abuse Treatment. Journal of Addictions \& Offender Counseling 36: 43-56.

22. Zuckoff A, Shear K, Frank E, Daley DC, Seligman K, et al (2006) Treating complicated grief and substance use disorders: A pilot study. Journal of substance abuse treatment 30: 205-211.

23. Kersting A, Brähler E, Glaesmer H, Wagner B (2011) Prevalence of complicated grief in a representative population-based sample. Journal of affective disorders 131: 339-343.

24. Stroebe M (2001) Gender differences in adjustment to bereavement: An empirical and theoretical review. Review of general psychology 5 : 62. 
Citation: Kheradmand A, Ghaffarinejad A, Anari AMZ, Noroozi F (2016) Complicated Grief in Iranian Methadone Maintenance Clients. Gavin J Addict Ther 2016: G109.

25. Schulz R, Boerner K, Shear K, Zhang S, Gitlin LN (2006) Predictors of complicated grief among dementia caregivers: a prospective study of bereavement. The American journal of geriatric psychiatry 14: 650658

26. Moss MS, Moss SZ, Hansson RO (2001) Bereavement and old age.

27. Keesee NJ, Currier JM, Neimeyer RA (2008) Predictors of grief following the death of one's child: The contribution of finding meaning. Journal of clinical psychology 64: 1145-1163.

28. Esmaeilpour K, Bakhshalizadeh Moradi S (2015) The Severity of Grief Reactions Following Death of First-Grade Relatives. Iranian Journal of Psychiatry and Clinical Psychology 20: 363-371.
29. Prigerson HG, Maciejewski PK, Reynolds CF, Bierhals AJ, Newsom JT, et al (2000) Inventory of Complicated Grief: a scale to measure maladaptive symptoms of loss. Psychiatry Research 59: 65-79.

30. O'Connor M, Lasgaard M, Shevlin M, Guldin M-B (2010) A confirmatory factor analysis of combined models of the Harvard Trauma Questionnaire and the Inventory of Complicated Grief-Revised: Are we measuring complicated grief or posttraumatic stress? Journal of Anxiety Disorders 24: 672-679. 